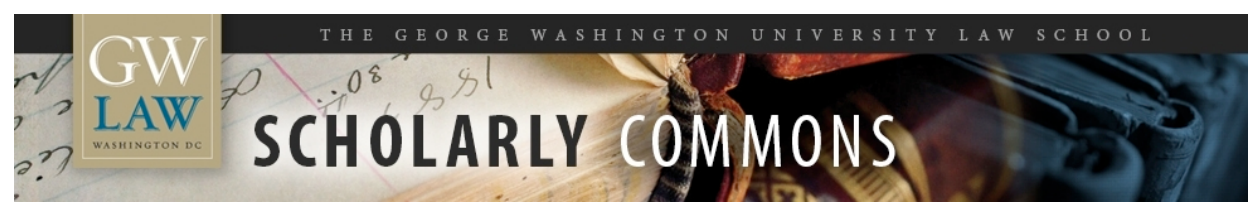

GW Law Faculty Publications \& Other Works

Faculty Scholarship

2018

\title{
§6.31 Excluding Felonies for Unfair Prejudice
}

Christopher B. Mueller

University of Colorado Law School

Laird Kirkpatrick

George Washington University Law School, lkirkpatrick@law.gwu.edu

Liesa Richter

University of Oklahoma College of Law

Follow this and additional works at: https://scholarship.law.gwu.edu/faculty_publications

Part of the Law Commons

\section{Recommended Citation}

Mueller, Christopher B. and Kirkpatrick, Laird C. and Richter, Liesa, §6.31 Excluding Felonies for Unfair Prejudice (2018). C. Mueller, L. Kirkpatrick, \& L. Richter, Evidence §6.31 (6th ed. Wolters Kluwer 2018); GWU Law School Public Law Research Paper No. 2018-70; GWU Legal Studies Research Paper No. 2018-70. Available at SSRN: https://ssrn.com/abstract=3277064

This Chapter is brought to you for free and open access by the Faculty Scholarship at Scholarly Commons. It has been accepted for inclusion in GW Law Faculty Publications \& Other Works by an authorized administrator of Scholarly Commons. For more information, please contact spagel@law.gwu.edu. 


\section{§6.31 Excluding Felonies for Unfair Prejudice}

Briefly put, courts may block impeachment by felony convictions on account of the risk of prejudice, and in this sensitive area FRE 609(a)(1) provides what might be called strong protection for criminal defendants and standard protection for other witnesses. The discretionary power to exclude felony convictions applies only to those that fit FRE 609(a)(1) alone. If they also fit FRE 609(a)(2) because they involve "a dishonest act or false statement," there is no discretion to exclude.

\section{When accused testifies}

Overwhelmingly the question whether to exclude felony convictions as prejudicial is a problem in criminal rather than civil cases, and almost always the issue arises when defendant testifies. The framers of FRE 609(a)(1) made the judgment that prior convictions are especially risky for criminal defendants and the language of FRE 609(a)(1)(B) is cast in favor of caution: The court is to allow impeachment by these first-prong felony convictions on determining that probative value outweighs prejudicial effect to the defendant. The strongly protective cast of the language favors excluding rather than admitting. It reverses the balance in FRE 403 (which generally favors admissibility), and such convictions should be excluded if probative worth and prejudicial effect seem equally balanced. ${ }^{1}$ For other witnesses, FRE 609(a)(1)(A) is cast in favor of admissibility, simply referring to FRE 403, which tells judges to admit unless probative value is "substantially outweighed" by unfair prejudice (or other dangers or concerns). Hence felony convictions are more likely to be admissible to impeach witnesses other than criminal defendants. ${ }^{2}$

Part of the problem for the accused is that using prior convictions to impeach him is likely to have a spillover effect, suggesting to factfinders that he likely committed the charged crime or is a bad person unworthy of sympathy, which raises the possibility of angry or emotional reaction or misuse of the conviction as evidence of guilt. Faced with such risks, defendants may elect not to testify, but staying off the stand is risky too: The rate of conviction is much higher for defendants who do not testify, ${ }^{3}$ and staying off the stand may result in keeping from the jury persuasive proof that the facts differ in important ways from what other evidence suggests.

\section{Gordon factors}

§6.31 1. See Christmas v. Sanders, 759 F.2d 1284, 1292 (7th Cir. 1985); United States v. Fountain, 642 F.2d 1083, 1092 (7th Cir. 1981), cert. denied, 451 U.S. 993.

2. Before the 1990 amendment, FRE 609(a)(1) only authorized exclusion of felony convictions on account of prejudice "to the defendant," which was interpreted to mean courts lacked authority to exclude first-prong convictions in civil cases. See Green v. Bock Laundry Mach. Co., 490 U.S. 504 (1989).

3. Self-selection probably skews the statistics, since a guilty defendant who cannot persuade factfinders of innocence is probably better off not testifying, and those who do testify may be "less guilty" than those who do not. See also $\S 6.35$, infra. 
In deciding whether to admit felony convictions, courts consider the circumstances of the trial, what the record discloses about convictions offered to impeach, and sometimes individual factors not disclosed on the face of a conviction or "rap sheet" or "case jacket." Two pathbreaking decisions in the District of Columbia circuit provide invaluable guidance for courts facing these issues. One is the decision in Gordon v. United States, which preceded the Rules but is highly respected in its outline of factors bearing on the exercise of discretion. The second is the en banc decision in United States v. Lipscomb, which acknowledges the Gordon factors and endorses a closer look at the individual facts that surround prior convictions. ${ }^{4}$ It is useful to look first to the Gordon factors and a few others that are important, then to consider the closer individual look suggested by Lipscomb.

\section{(1) Nature of prior crime}

Many felonies (from drug use to bank robbery) bear only generally on credibility, and FRE 609(a)(1) invites courts to consider gradations in probative worth. The nature of the prior crime is perhaps the salient point. Gordon suggested that "deceit, fraud, cheating, or stealing" reflect adversely on honesty and integrity, but that crimes of "violence" may reflect such qualities as "short temper, a combative nature, extreme provocation, or other causes" and generally have "little or no direct bearing” on veracity.

\section{(2) Recency or remoteness}

Some felonies are directly related to veracity in the sense of exemplifying untruthful behavior. But most such crimes also fit FRE 609(a)(2), where courts have no discretion to exclude (felony convictions for fraud, embezzlement, false statement or pretense, perjury or suborning perjury are usually admissible automatically). Even so, some crimes that do not fit FRE 609(a)(2) fall relatively high on the scale of probative worth on veracity, including especially crimes of theft and receiving stolen property. Similarly high on the scale are crimes that involve evasions of responsibility or abuse of trust, a category that includes smuggling or failure to register or report when required, and at least sometimes drug importation and even sexual abuse of children in

defendant's care. ${ }^{5}$ Others fall lower on the scale, including especially crimes in which violence is

4. See United States v. Lipscomb, 702 F.2d 1049, 1062-1071 (D.C. Cir. 1983) (quoted in this section by reference to case name) (opinion by Judge Wald); Gordon v. United States, 383 F.2d 936, 940-941 (D.C. Cir. 1967) (quoted in this section by reference to case name) (opinion by Judge, later Chief Justice, Burger), cert. denied, 390 U.S. 1029. See also United States v. Montgomery, 390 F.3d 1013, 1015 (7th Cir. 2004) (citing Gordon factors), cert. denied, 544 U.S. 968.

5. United States v. Estrada, 430 F.3d 606, 616 (2d Cir. 2005) (crimes like smuggling or failure to register and report, and other involving "evasions of responsibility or abuse of trust" are relatively high in probativity) (quoting this Treatise), cert. denied, 547 U.S. 1048; United States v. Alexander, 48 F.3d 1477, 1488 (9th Cir. 1995) (robbery is probative of veracity), cert. denied, 516 U.S. 878; United States v. Halbert, 668 F.2d 489, 495 (10th Cir. 1982) (mail fraud, false pretenses, aggravated robbery were "not unrelated" to truthfulness; fraud and false pretenses were directly relevant), cert. denied, 456 U.S. 1038. 
the central feature, which in turn embraces many sex offenses. ${ }^{6}$ Also low on the scale are many drug crimes, and crimes against public morality, such as prostitution. ${ }^{7}$

Arguably, however, crimes requiring planning or preparation bear more strongly on veracity than violence alone suggests because planning indicates deliberate and injurious violation of basic standards rather than impulse or anger, and usually it involves some element of deceiving the victim. ${ }^{8}$ The logic that underlies FRE 609(a) implies that the gravity of an offense bears on truthfulness on the theory that more serious offenses suggest stronger willingness to ignore legal obligations.

Even a conviction for a crime that has high probative worth on veracity should be excluded, the court in Gordon said, "if it occurred long before and has been followed by a legally blameless life.” FRE 609(b) creates in effect a presumption that a conviction more than ten years old should be excluded, but even the age of a more recent conviction may tip the balance in favor of exclusion. ${ }^{9}$ As Gordon suggests, the remoteness factor is affected by the presence or absence of more recent convictions, in part because a more recent conviction suggests that defendant has not changed his ways and in part because later convictions strengthen the inference that defendant is willing to violate the law. ${ }^{10}$

\section{(3) Similarity to charged crime}

When the accused is a witness, the closer the resemblance between the charged crime and the crime leading to the prior conviction offered, the greater the potential prejudice. In Gordon, the court said that prior convictions for the same crime "should be admitted sparingly," suggesting that the court might limit the impeachment by similar crimes to a "single conviction." Of course some resemblances between the prior and the charged offense justify admitting evidence of the former on such points as knowledge, motive, intent, and so forth under FRE 404(b). ${ }^{11}$ But a crime

6. Procknow v. Curry, 826 F.3d 1009, 1012-1013 (8th Cir. 2016) (conviction for attempted murder was prejudicial and had "quite limited" probative worth on veracity); Christmas v. Sanders, 759 F.2d 1284, 1292 (7th Cir. 1985) (rape “not highly probative of credibility”).

7. United States v. Martinez, 555 F.2d 1273, 1276 (5th Cir. 1977) (aiding and abetting drug crime had "slight" probative value); United States v. Cox, 536 F.2d 65, 71 (5th Cir. 1976) (prostitution conviction was immaterial).

8. United States v. Fountain, 642 F.2d 1083, 1091-1092 (7th Cir. 1981) (premeditated murder "involves deliberation," meaning one is likely “willing to lie” on stand), cert. denied, 451 U.S. 993.

9. United States v. Beahm, 664 F.2d 414, 419 (4th Cir. 1981) (reversible error to admit nine-year-old conviction, partly because it was so remote); United States v. Shapiro, 565 F.2d 479, 481 (7th Cir. 1977) (reversing conviction mainly because of remoteness of convictions used to impeach).

10. United States v. Lipscomb, 702 F.2d 1049, 1071 (D.C. Cir. 1983) (defendant could be impeached by eight-yearold robbery conviction; he was repeat offender with more recent conviction, which enhances probativity of robbery conviction by showing it "was not merely an isolated criminal episode”).

11. See generally §§4.15-4.18, supra. 
may easily lead to conviction for the same offense without being sufficiently relevant on some particular point to be admissible under FRE 404(b), and then use of the conviction to impeach the defendant introduces the risk of prejudice that is the concern of FRE 609(a)(1), and for that matter the concerns of FRE 403 and 404. ${ }^{12}$

\section{(4) Extent and nature of record}

As Gordon and Lipscomb recognize, probative value may be affected by defendant's whole criminal record. All other things being equal, an isolated conviction by one who otherwise leads a "blameless life" carries less probative worth on credibility than a conviction that fits a pattern of criminal behavior. ${ }^{13}$ Other convictions need not necessarily be mentioned in questioning, but appropriately bear in the court's balance of the risks of prejudice against probative value of convictions that are mentioned.

\section{(5) Importance of defendant's testimony}

For a defendant with a criminal record, the question whether to take the stand is very much affected by the prospect of impeachment by convictions. Gordon noted that the judge may decide it is more important for the jury to have the benefit of the defendant's testimony than to have him remain silent out of fear of impeachment. ${ }^{14}$

\section{(6) Importance of credibility issues}

The court in Gordon approved use of prior convictions in part because the trial "had narrowed to the credibility" of defendant and his accuser so there was more reason "to shed light on which of the two witnesses was to be believed" (the accuser himself had been impeached by convictions,

12. Robinson v. State, 717 S.E.2d 694, 697 n.3 (Ga. App. 2011) (conviction involving “conduct similar to the conduct for which the defendant is being tried” brings increased risk that jury will take it as proof that defendant "probably engaged in the conduct for which he is being tried") (citing this Treatise); United States v. Jiminez, 214 F.3d 1095, 1098 (9th Cir. 2000) (in felon-in-possession trial, should not have admitted conviction for assault with deadly weapon).

13. State v. Zornes, 831 N.W.2d 609, 627 (Minn. 2013) (defendant spent most of the time between earliest offense and trial in prison, which "weighs strongly in favor” of probative value); United States v. Lipscomb, 702 F.2d 1049, 1071 (D.C. Cir. 1983) (being repeat offender enhanced probativity of earlier conviction; it was not "isolated criminal episode”).

14. Gordon v. United States, 383 F.2d 936, 940-941 \& n.11 (D.C. Cir. 1967) (where intent or knowledge is proved circumstantially, as from “unexplained possession of recently stolen property,” importance of getting defendant's testimony is greater), cert. denied, 390 U.S. 1029. See also United States v. Browne, 829 F.2d 760, 763-764 (9th Cir. 1987); United States v. Oakes, 565 F.2d 170, 173 (1st Cir. 1977) (justice may be advanced if defendant is not "demoralized from taking the stand by fear that a prior conviction would overshadow" positive aspects of his testimony). 
seemingly enhancing the need to reveal similar shortcomings in defendant's veracity), and the importance of credibility issues counts in the balance. ${ }^{15}$

\section{(7) Other factors}

Other factors bear on the problem. Courts may consider the larger picture of criminal behavior in which a conviction is an element and take into account the role of the witness and the general nature of the criminal enterprise. ${ }^{16}$ And the court may take into account any overlap between the criminal behavior underlying a conviction and the behavior leading to present charges, which raises special concerns by making it harder to avoid misusing the conviction as proof of present guilt. ${ }^{17}$ Arguably a conviction after a plea of not guilty has more probative worth than one based on a guilty plea because the former suggests that defendant took a position (or gave testimony) that the factfinder found to be false. ${ }^{18}$

No thoughtful person is likely to be satisfied with any list of factors. In the setting of FRE 609(a)(1), dishonesty and untruthfulness are not likely to be elements in the offense, and crimes are defined for the purpose of determining criminal responsibility rather than measuring veracity. Hence it is not surprising that courts exercising discretion under FRE 609 look behind those elements to particular facts and circumstances and to the more general picture of criminality that convictions suggest. In Lipscomb, the court provided useful guidance on the procedure and mechanics of taking a closer look. There the government argued that the court should decide without inquiring into underlying facts, relying on the name of the offense, underlying elements, and date of conviction (the judge also knew defendant was only 16 years old when convicted). The defense argued that the court erred in failing to conduct a fuller inquiry, and that in all but the simplest cases such inquiry is essential. Lipscomb staked out a middle ground. It held that a court may inquire into the underlying facts and ask the government to produce the necessary data, but it declined to set up "general guidelines" to decide when "inquiry beyond the name and date" of conviction is necessary and left the matter to the judge's discretion. The court commented that often a judge "may be satisfied" with readily available information such as a "case jacket or

15. United States v. Johnson, 302 F.3d 139, 152 (3d Cir. 2002) (approving questions on felony convictions; credibility was “major issue” because defense depended on jury “believing his story”); United States v. Perkins, 937 F.2d 1397, 1407 (9th Cir. 1991) (admitting bank robbery conviction since defendant’s credibility and testimony were central).

16. United States v. Ortiz, 553 F.2d 782, 784 (2d Cir. 1977) (drug trafficker lives life of “secrecy and dissembling” probative of credibility), cert. denied, 434 U.S. 897.

17. Compare United States v. Martinez, 555 F.2d 1273, 1276 (5th Cir. 1977) (in drug trial, reversible error to let prosecutor ask about defendant's conviction for aiding and abetting in offense being tried) with United States v. De La Torre, 639 F.2d 245, 248-249 (5th Cir. 1981) (approving questions to defendant on perjury conviction stemming from testimony he gave at first trial on same charges).

18. Gordon v. United States, 383 F.2d 936, 940 n.8 (D.C. Cir. 1967) (probative value varies between convictions based on guilty pleas and those following trial in which defendant testifies, where verdict amounts to finding that defendant "did not tell the truth when sworn to do so"), cert. denied, 390 U.S. 1029. 
presentence report" and that in deciding whether to pursue additional facts the judge could consider the burden or delay that would be entailed.

Still, Lipscomb encouraged trial courts to engage in a factual inquiry. Invoking legislative history and the "plain meaning" of FRE 609, Lipscomb said this approach is the wisest one and that factual data is often useful. In an important clue acknowledging the worth of such inquiry, the court commented that with felony convictions the question of prejudice "is not if, but how much." Finally, the court noted that the prosecutor should routinely have "at least some details of the defendant's own past convictions" because the government is expected to consider such details before deciding whether to seek an indictment, which charges to bring, and what sort of plea bargain to offer. Assuming additional inquiry is pursued, Lipscomb cited examples to suggest facts that bear on admissibility-a manslaughter conviction arising from an incident where a man shot his wife and her lover, a case where defense witnesses were serving substantial prison terms and would have a motivation to testify falsely in a dispute with prison guards, a case where the crime was committed when defendant was only 20 years old, and finally a case in which defendant had been convicted after testifying in his own defense.

\section{Witnesses other than the accused}

For witnesses other than defendants in criminal trials, FRE 609(a)(1)(A) incorporates the balancing standard of FRE 403, so in these other settings felony convictions are admissible unless probative worth is substantially outweighed by the risk of prejudice or any of the dangers and concerns listed there. Use of convictions to impeach defense witnesses in criminal cases could have a spillover effect, causing prejudice to defendants by association, but such convictions are less dangerous to defendants than their own. Judging the prejudice issue by a standard cast more in favor of admissibility seems justified. Under FRE 609, the government also can seek to block defense impeachment of its witnesses under FRE 403, but such objections seldom succeed. ${ }^{19}$

Perhaps it is in the nature of things that witnesses called in civil cases are seldom impeached by prior convictions. In the case of impeaching the litigants themselves, many of the factors discussed above apply in this setting too-the question whether to admit or exclude felony convictions in civil actions is affected by the nature of the conviction, its similarity (if any) to the conduct in issue in the suit, and the importance of credibility issues. ${ }^{20}$

19. Green v. Bock Laundry Mach. Co., 490 U.S. 504 (1989) (FRE 609 “limits impeachment of not only a criminal defendant, but also any witness offered on the defendant's behalf”) (before 1990 amendment). Compare State v. Randall, 639 N.W.2d 439, 447-448 (N.D. 2002) (in trial for attempted murder, error to exclude felony convictions of alleged victim; courts rarely exclude convictions impeaching prosecution witnesses; prosecutor bears burden of showing that unfair prejudice outweighs probative worth; error harmless) (quoting authors of this Treatise) with United States v. Galati, 230 F.3d 254, 261-262 (7th Cir. 2000) (blocking defense effort to impeach government witness; applying FRE 403).

20. Wierstak v. Heffernan, 789 F.2d 968, 972 (1st Cir. 1986) (nature); Murr v. Stinson, 752 F.2d 233, 234-235 (6th Cir. 1985) (recency and nature). 